\title{
Yazma Güçlüğü (Disgrafi) Olan Bir İlkokul 2. Sınıf Öğrencisinin El Yazısı Okunaklılığının Geliştirilmesi: Eylem Araştırması
}

Mustafa Yildiz*

\section{Özet}

Bu çalışma, ilkokul ikinci sınıfta öğrenim gören ve yazma güçlüğü olan bir öğrenicinin el yazısı okunaklılı̆̆ının geliştirilmesi amacıyla gerçekleştirilmiştir. Çalışma, bir öğretmenin öğrencisinin yazma konusunda yaşadığı soruna çözüm üretme sürecini kapsadığından uygulamalı eylem araştırması olarak tasarlanmıştır. Öğrenci, Ankara'da kamuya ait bir ilkokula devam etmektedir ve birinci sınıftan itibaren araştırmacının öğrencisidir. Öğrencinin yazma güçlüğünün nedenlerinin anlaşılması için öğrenci sınıfta ve teneffüste gözlemlenmiş, ebeveynleriyle görüşülmüş, sağlık raporları, çalışma kitapları ve defterleri incelenmiştir. Bu incelemeler sonunda öğrencinin yazma güçlüğünün daha çok gelişimsel koordinasyon bozukluğundan (GKB) kaynaklandığı sonucuna ulaşılmıştır. Öğrencinin okunaklı yazma becerisini geliştirmek için büyük kas hareketlerinden küçük kas hareketlerine doğru aşamalandırılmış bir yazı öğretimi eylem planı hazırlanarak uygulanmıştır. Yedi hafta süren uygulamada 35 ders gerçekleştirilmiştir. Öğrencinin yazı okunaklılığındaki gelişimi belirleyebilmek için uygulama öncesi ve sonrası kopyalama ve dikte çalışmaları yapılmıştır. Yazının okunaklılık düzeyi Çok Boyutlu Okunaklılık Ölçeği ile değerlendirilmiştir. Sonuç olarak uygulamanın başarılı olduğu, öğrencinin okunaklılık bakımından yetersiz olan yazısının orta düzeyde okunaklı bir seviyeye ulaştı̆̆ı görülmüştür. Çalışma, uygun yöntem ve tekniklerle yazma güçlüklerinin giderilebileceğini ve öğretmenlerin yazma güçlüğü olan öğrencilerine destek olabileceğini göstermiştir.

Anahtar Sözcükler : yazma güçlüğü, disgrafi, okunaklılık, eylem araştırması

Development of the handwriting legibility of a $2^{\text {nd }}$ grade Turkish student with disgraphia: Action Research

\footnotetext{
Abstract

* Öğr. Gör. Dr. Gazi Eğitim Fakültesi, Sınıf Öğretmenliği Eğitimi ABD, mustafa@gazi.edu.tr.
} 
The purpose of this research was to explore the development of handwriting legibility of a second grade student with dysgraphia. This action research focused on a teacher's practices and strategies to help the student with dysgraphia to improve his writing legibility. The participating student was a student in a public school setting in Ankara and a student in the researcher's classroom science his first grade. Based on observations, health reports, parents' thoughts and the student's hand writing workbook reports, the student's dysgraphia was resulted by developmental coordination disorder (DCD). Seven week long and 35 session action plan including sequences from big muscle movements to small muscle movements was proceeded to help the student to develop better handwriting legibility. To increase the legibility of the student's handwriting, before and after the action copying and dictation applications were carried out. The readability level of his handwriting was measured by the Multidimensional Legibility Scale. Findings indicated that the action plan was successfully shifted this student's handwriting legibility level from inappropriate to moderate level. Thus, by effective methods and procedures teachers may help students with dysgraphia to develop better handwriting legibility. research

Keywords : writing difficulties, dysgraphia, legibility, action

\section{Giriş}

Yazma, bilişsel, kinestetik ve algısal motor bileşenlerden oluşan karmaşık bir etkinliktir (Engel-Yeger, Nagauker-Yanuv ve Rosenblum, 2009). Yazı, eğitim kariyerleri boyunca öğrencilerin düşüncelerini ifade etmelerini, kayıt etmelerini ve dönüştürmelerini sağlayan en önemli iletişim aracıdır (Dennis ve Swinth, 2001). Okulda öğrenme öğretme süreçlerinde yapılan çalışmaların önemli bir kısmı yazmaya dayalı olarak yürütülmektedir. Yazı okul çağı çocuklarının duygu ve düşüncelerini ifade etmek için uygun sürede, okunabilir bir ürün oluşturmalarını sağlayan en temel etkinliktir (Erhardt ve Meade, 2005; Rosenblum, Weiss, ve Parush, 2003). Ortalama bir öğrencinin okul gününün \%30 ile \%60'ı arası bir zaman diliminde iyi bir yazma becerisine ihtiyacı vardır (McHale ve Cermak, 1992). $\mathrm{Bu}$ durum öğrencilerin biçimsel olarak okunaklı, içerik olarak da iyi organize edilmiş yazılı ürünler oluşturmalarını gerekli kılmaktadır. Ancak bazı öğrencilerin yazma becerisini kazanmada sorun yaşadıkları 
bilinmektedir. Bu sorunlar giderilmediğinde öğrencilerin öğrenme sürecinde ciddi sıkıntılar yaşamaları muhtemeldir.

Araştırmalar öğrencilerin \%10-\%34'lük bir oranının okul çalışmalarının gerektirdiği el yazısı yeterliliğine sahip olmadıklarını göstermektedir (Smits-Engelsman, Niemeijer ve Van Galen, 2001). El yazısı yeterliliği gelişmemiş olan bu çocuklar "el yazısı zayıf olan" veya "disgrafili" olarak tanımlanmaktadır (Marr ve Cermak, 2001). El yazısı güçlüğü veya disgrafi, yazılı dilin üretilmesinde el yazısı mekaniğiyle ilişkili olan güçlükler ya da bozukluklar olarak ifade edilmektedir (HamstraBletz ve Blote, 1993). Öğretmenler el yazısı güçlüklerinin kız öğrencilerde görülme oranının \%10-11, erkek öğrencilerde ise \%21-32 olduğunu belirtmektedirler (Rubin ve Henderson, 1982). Disgrafi veya el yazısı yetersizlikleri diğer akademik yetersizlikleri olsun ya da olmasın öğrenme güçlügü olan çocuklar ve yetişkinler arasında, öğretmenleri tarafından sakar olarak tanımlanan gelişimsel koordinasyon bozukluğu (GKB) olan çocuklarda görülen en yaygin sorundur (Cratty, 1994; Johnson, 1995; Waber ve Bernstein, 1994; Laszlo, 1990; Laszlo, Bairstow ve Bartip, 1988).

$\mathrm{Bu}$ araştırmada el yazısı okunaklılığı geliştirilmeye çalışılan öğrencinin özellikleriyle de ilişkili olduğundan gelişimsel koordinasyon bozukluğunun (GKB) biraz detaylandırılması gerekmektedir. GKB tanısının temel özelliği, motor koordinasyonu gerektiren günlük etkinliklerde kişinin yeterliliğinin kronolojik yaşı, ölçülen zeka düzeyi göz önüne bulundurulduğunda beklenenin önemli ölçüde altında olmasıdır. Bu durum, motor dönüm noktalarına (ör. yürüme, emekleme, oturma) ulaşmada belirgin gecikmelerin olması, eşyaları düşürme, hantallık, spor yaparken düşük yeterlilik gösterme ya da el yazısının bozuk olması ile kendini gösterebilir (Diagnostic and Statistical Manual of Mental Disorder-IV-TR, [DSM-IV-TR], 2007; Rosenblum, Aloni ve Josman, 2010). GKB, çocukların okul, ev ve diğer sosyal ortamlarda motor performans gerektiren günlük işlerdeki yetenekleriyle ilgilidir. GKB olan çocuklarda genel motor performansta yaşanan güçlüklerden kaynaklanan el yazısı yetersizlikleri görülmektedir. GKB olan öğrencilerin, el yazısı güçlüklerinin yanı sıra öz bakım becerilerinde, evdeki görev ve etkinliklerde, spor etkinliklerinde ve çeşitli okul çalışmalarında güçlük yaşadıkları belirtilmektedir (Cermak, 1985; MayBenson, Ingolia, ve Koomar, 2002).

Disgrafili çocuklar uygun şekilde okuyabilir fakat yazamazlar. Bu yazamama hiçbir şey yazamama anlamına gelmez. Disgrafi, genellikle 
okunaklılık ve yazma hızının yavaşlığı konusunda yaşanan sorunlarla kendini göstermektedir. Disgrafili çocuklar harf boyutlarını doğru ve uygun yazmazlar, harf aralarındaki boşlukları ayarlayamazlar ve kelimeleri yanlış ve eksik yazarlar (Akyol, 2011a; Feder ve Majnemer, 2007). Bu durum yazma güçlüklerinin öğrencilerin akademik başarısını da olumsuz yönde etkilemesine neden olmaktadır. Yazma güçlüklerinin öğrencilerin akademik başarısını iki temel nedenden dolayı olumsuz etkilediği belirtilmektedir. Birinci neden, el yazısı mekaniğinde yaşanan sorun öğrencilerin iyi bir kompozisyon oluşturmak için ihtiyaçları olan bilişsel süreçleri kullanmalarını engellemesidir. Bu durum yazılı ürünlerin niteliğini ve niceliğini de olumsuz etkilemektedir (Berninger ve Graham, 1998; Berninger ve Hooper, 2006; Graham, 1990). Yazının mekaniğinde yaşanan sorun yazının okunaklılığını olumsuz etkiler. Okunaklılık, okuyucuya sunulan el yazısında harflerin ifade yeterliliğini gösterir (Ediger, 2001). Harflerin otomatik ve akıcı bir şekilde üretilememesi, zihinsel süreçlerin ve dikkatin kompozisyon yazmak için yeterli düzeyde kullanılmasını engellemektedir (Jones ve Christensen,1999; Berninger ve Graham, 1998). Buna ek olarak el yazısı yavaşlı̆̆ının öğrencilerin yazmayı tasarladıkları kimi fikirleri unutmalarına neden olabileceği belirtilmektedir (Graham ve Weintraub, 1996). El yazısı güçlüklerinin akademik başarıyı olumsuz yönde etkilemesine neden olan ikinci durum ise öğretmenlerin okunaklılık bakımından iyi olan yazılara daha fazla not verme eğiliminde olmalarıdır (Graham, Harris, ve Fink, 2000). Bu durum kötü el yazısının, öğrencilerin yazma becerileri konusunda yanlış algıların oluşmasına neden olmasından kaynaklanmaktadır (Rosenblum, Weiss ve Parush, 2004). Buna ek olarak, disgrafili öğrenciler sınıfta el yazısıyla ilgili verilen görevleri tamamlamak için daha fazla zamana ihtiyaç duyarlar, yapılan yazı çalışmalarını özellikle de tahtadakileri deftere yazmada güçlük yaşarlar, ev ödevlerini tamamlayabilmek için çok fazla zamana ihtiyaç duyarlar (Graham, Struck, Santoro, ve Berninger, 2006; Sovik, Arntzen, ve Karlsdottir, 1993). Disgrafili öğrencilerin akademik süreçlerde başarılı olabilmeleri ve dezavantajlı duruma düşmemeleri için desteklenmeleri ve yazma becerilerinin geliştirilmesi gerekmektedir.

Disgrafili öğrenciler yalnızca akademik olarak değil sosyal ve psikolojik alanlarda da sorun yaşayabilirler. El yazısı güçlüğü yaşayan öğrencilerin ebeveynlerin beklentilerini tam olarak karşılamada ve sınıf görevleriyle baş etmede zorlanacakları belirtilmektedir (Sovik, Arntzen, ve Karlsdottir, 1993). Dahası el yazısında zorlanan bazı öğrenciler artık iyi bir yazı yazmayacakları yönünde bir inanç geliştirebilirler (Berninger ve 
Graham, 1998). Bu açıdan düşünüldüğünde disgrafili öğrencilerin desteklenmesi onların sosyal ve psikolojik alanlarda yaşayacakları sorunların da giderilmesini sağlayacaktır. Disgrafili öğrencilerle yürütülecek çalışmalar da bu durum dikkate alınmalı, çalışma sürecinde akademik becerileri geliştirmenin yanı sıra psiko-sosyal süreçler de önemsenmelidir. Richards (1999) disgrafili öğrencilerin desteklenmesi sürecinde uyum ve iyileştirme olmak üzere iki temel stratejiden bahsetmektedir. Uyum stratejileri, öğrenme üzerinde negatif etkisi olan problemlerin azaltılmasını, iyileştirme stratejileri ise yeni kavram ve becerilerin öğretiminde öğrencinin öğrenme stiline ve ihtiyaçlarına uygun yapılandırılmış tekniklerin kullanılmasını içermektedir

Türkiye'de yazma güçlüklerinin giderilmesine yönelik çalışmalar oldukça sınırlıdır. Bu konudaki çalışmalardan birisi Çinar-Özdemir (2006) tarafından yürütülmüştür. Fizyoterapist olan araştırmacı disgrafili öğrencilere 8 hafta süreyle üst ekstremite motor eğitimi (omuz, kol ve el kaslarının kuvvetlendirilmesine yönelik eğitim) vermiştir. Haftada üç gün 35-40 dakikalık seanslardan oluşan program kasları kuvvetlendirmeye yönelik fiziksel etkinlikler içermektedir Araştırma sonucunda omuz, kol ve el kaslarının birlikte çalıştırılmasına yönelik etkinliklerin öğrencilerin yazı okunaklılığına, kas kuvvetine, ince el becerilerine ve kaba kavrama kuvveti değerlerine olumlu katkı sağladığı görülmüştür. Yazma güçlüklerinin giderilmesine yönelik diğer bir araştırmada (Calp, 2013), el yazısı problemi olan bir öğrencinin yazma probleminin giderilmesi için 30 saatlik bir çalışma yürütülmüştür. Çalışmada harf öğretimi (harflerin yazılış biçimi, yönü, satırda kapladıkları alan, büyük küçük harf ilişkisi) ve noktalama işaretlerinin öğretiminin yanı sıra kalem tutma, sırada oturma ve defter tutmaya ilişkin becerilerinin kazandırılmasını içeren etkinlikler yapılmıştır. Çalışma sonunda öğrencinin yazma hataları azalmış ve yazısı okunaklılık bakımından kabul edilebilir bir düzeye gelmiştir.

$\mathrm{Bu}$ çalışmanın amacı, yazma güçlüğü olan bir ilkokul ikinci sınıf öğrencisinin el yazısı okunaklılığı eylem araştırması çerçevesinde geliştirmek ve eylem sürecini betimlemektir. Bu çalışma aracılığıyla yazma güçlüklerinin giderilmesine yönelik örnek bir uygulama konuyla ilgilenenlerle paylaşılmaktadır. Bu çalışma yazma güçlükleri konusunda var olan eksikliğin giderilmesine katkı sağlamasından dolayı önem taşımaktadır.

\section{Yöntem}




\section{Araştırmanın Modeli}

Çalışma, bir öğretmenin öğrencisinin yazma konusunda yaşadı̆̆ 1 soruna çözüm üretme sürecini kapsadı̆̆ından uygulamalı eylem araştırmasıdır. Eylem araştırmaları uygulamalı ve katılımcı olmak üzere iki grupta ele alınmaktadır (Mills, 2000). Uygulamalı eylem araştırmaları, öğretmenlerin sınıflarında karşılaştıkları bir soruna çözüm üretmek, herhangi bir konuda öğrencilerinin öğrenme düzeyini geliştirmek ve kendi mesleki performanslarını artırmak için tasarladıkları araştırmalardır (Creswel, 2005). Sınıfta gerçekleştirilen eylem araştırmalarında teorilerden çok sorunu gidermeye yönelik uygulama ve etkinlikler ön plândadır (Kemmis ve McTaggart, 2000). Araştırmacı bu çalışmayı yürütürken hem öğretmenlik yapmakta hem de sınıf öğretmenliği eğitimi alanında doktora öğrenimine devam etmekteydi. Çalışma sürecinde ihtiyaç duyulduğunda okuma yazma güçlükleri konusunda deneyimli akademisyenlerin görüşüne başvurulmuştur.

\section{Katılımcı}

Araştırma kapsamında yazı okunaklılı̆̆ geliştirilmeye çalışılan öğrencinin gerçek kimliğinin deşifre olmaması için kod adı olarak Ali kullanılmaktadır. İlköğretim ikinci sınıf öğrencisi olan Ali, Ankara'da kamuya ait bir ilkokula devam etmektedir ve birinci sinıftan itibaren araştırmacının öğrencisidir. Öğrenme güçlüklerinde tanı konulması için ikinci sınıfın daha uygun olduğu belirtilmektedir (DSM-IV-TR, 2007). Bu açıdan Ali'nin yazma konusunda yaşadığı güçlüğün tanılanması ve giderilmesine yönelik çalışma öğrenci ikinci sınıfa devam ederken yürütülmüştür. Bu tür çalışmalarda katılımcıyla ilgili detaylı bilgiye sahip olunmasi gerekmektedir.

Bunun için Ali sınıfta ve teneffüste gözlemlenmiş, Ali'nin ebeveynleriyle görüşülmüş, sağlık raporları, çalışma kitapları ve defterleri incelenmiştir. Ali, ilk okuma yazmayı arkadaşlarıyla birlikte öğrenmiştir. Dişlerindeki eksiklerden dolayı sesli okumada bazı telaffuz sorunları yaşamaktadır. Okuduğunu anlamada ve matematikte akranlarından geridedir. Ayrıca sportif etkinliklerde (koşma, futbol oynama, top atmatutma vb.) akranları kadar yeterli değildir. Buna ek olarak ayakkabı bağlarının açıklığı, pantolon düşüklüğü, ders araç gereçlerini düşürme, kaybetme, arama gibi durumlar Ali'de sık sık gözlemlenmektedir.

Ali arkadaşları tarafından sevilen, teneffüslerde arkadaşlarıyla oynayan, öğretmeni ve arkadaşlarıyla iletişim kurmakta zorlanmayan 
sevimli bir öğrencidir. Ailenin tek çocuğu olan Ali'nin babası işçi, annesi ev hanımıdır. Ebeveynleri Ali'nin konuşma ve yürüme becerilerini kazanmada yaşıtlarına göre gecikmeler olduğunu belirtmişlerdir. Ebeveynler, Ali'nin gelişmesini desteklemek için ilaç kullandıklarını ve bazı dişlerinin henüz çıkmadığını belirtmişlerdir. Okul performansı bakımından Ali'yi en zayıf buldukları dersin matematik olduğunu ifade etmişlerdir. Ebeveynler Ali'nin yazdıklarını hiç okuyamadıklarını, el yazısının çok bozuk olduğunu özellikle vurgulamışlardır. Ali'nin araştırmaya katılımı ve araştırma raporunda fotoğrafların kullanımı konusunda ebeveynlerin onayı alınmıştır.

\section{Çalışma Çevresi ve Ortam}

Çalışma katılımcının devam ettiği sınıfta gerçekleştirilmiştir. Sınıfta kırk öğrenci bulunmaktadır. Okulun bulunduğu bölge itibariyle sınıftaki öğrencilerin çoğunluğu orta ve orta altı sosyoekonomik düzeye mensup ailelerin çocuklarıdır. Sınıfta okuma yazmayı bilmeyen öğrenci yoktur. Öğrenciler arasında akademik başarı bakımından düzey farklılıkları mevcuttur. Öğretmen öğrencileriyle yakından ilgilenmekte, bireysel farklılıklarını önemsemekte ve sınıf içi etkinliklerde her öğrencinin potansiyelini geliştirmeye dönük bir yaklaşım izlemektedir. Öğrencilerin okula ve öğrenmeye yönelik ilgileri yüksektir.

Öğretmen öğrencilerin ebeveynleriyle sik sık görüşmekte, ebeveynlerin görüş, istek ve taleplerine duyarlı bir tutum sergilemektedir. Ebeveynlerle kurulan etkili iletişim öğrenme öğretme sürecine olumlu katkı sağlamaktadır. Araştırmacının bu çalışmayı planlayıp yürütmesinde etkili olan faktörlerden birisi de Ali'nin annesinin bu konudaki isteğidir. Sınıftaki diğer öğrencilere Ali ile birlikte yürütülecek çalışma hakkında uygun bir anlatımla bilgi verilmiştir. Çalışma sürecinde Ali arkadaşlarının herhangi bir olumsuz tutum ve davranışına maruz kalmamıştır.

\section{Veri Toplama Araçları}

Kopyalama ve Dikte Metinleri: Uygulanan etkinliklerin Ali'nin okunaklı yazma becerisindeki gelişime etkisini değerlendirebilmek için Ali'ye uygulama öncesi ve uygulama sonrası iki kısa metin yazdırılmıştır. Metinlerden birisi 'Ali ile Veli' adlı beş cümlelik dikte metni, diğeri de kopyalama (bakarak yazma) şeklinde yazılan 'Bayrağım' adlı şiirdir. Dikte metni araştırmacı tarafından oluşturulmuştur. Dikte metninin günlük hayatan sözcükler içermesine ve olabildiğince harf çeşitliliğine sahip olmasına dikkat edilmiştir. Kopyalama metni ise ikinci sınıf düzeyi bir Türkçe ders kitabından alınmıştır. 
Çok Boyutlu Okunaklılık Ölçeği: Çok Boyutlu Okunaklılık Ölçeği (Yıldız ve Ateş, 2010) yazı okunaklılığını eğim, boşluk, ebat, biçim ve çizgi takibi olarak beş boyutta değerlendiren bir dereceli puanlama anahtarıdır. Ölçekte okunaklılığın boyutları yeterli (3), kısmen yeterli (2), yetersiz (2) olarak üç kategoride ele alınmış ve yeterlilik düzeyleri tanımlanmıştır. Ölçekten alınabilecek en düşük puan 5, en yüksek puan $15^{\prime}$ tir. Toplam puanı 5 - 8.3 olan yazılar okunaklı değil; toplam puanı 8.4 - 11.7 olan yazılar orta düzeyde okunakli; toplam puanı 11.8 - 15 olan yazılar ise, okunaklı olarak değerlendirilmektedir.

Araştırma Günlü̈̆ü: Günlükler ve alan notları nitel araştırmalarda önemli veri toplama araçlarıdır (Creswel, 2005). Bu açıdan araştırma sürecinde araştırma günlüğü tutulmuştur. Günlük, araştırmacının hem sürece ilişkin betimlemelerini hem de uygulanan stratejilere eleştirel yaklaşımını içermektedir. Sürece ilişkin betimlemeler katılımcının performansına, ilgisine, başarı ya da başarısızlıklarına vurgu yapmaktadır. Stratejilere eleştirel yaklaşım ise uygulanan etkinliğin işe yarayıp yaramadığına ilişkin araştırmacının değerlendirmelerini ifade etmektedir. $\mathrm{Bu}$ durum araştırmada kullanılan stratejilerin geliştirilmesini sağlayarak amaca daha fazla hizmet edebilecek tekniklerin oluşturulmasına katkı sağlamıştır.

Görüşme: Araştırma sürecinde zaman zaman katılımcıyla ve ebeveynleriyle sohbet tarzında görüşmeler yapılmıştır. Yıldırım ve Şimşek'e (2000) göre, bu yaklaşım genellikle araştırmacının doğrudan ortama katıldığı araştırmalarda kullanılır. Görüşülen birey kendisiyle görüşme yapıldığını fark etmeyebilir. Önceden belirlenmiş sorular yoktur, sorular konuşmanın anlık akışı içinde kendiliğinden gelişir.

\section{Verilerin Analizi}

Kopyalama ve dikte metinleri Ali'nin okunaklı yazma düzeyine karar verebilmek ve uygulamanın okunaklılığa katkısını ortaya çıkarabilmek için kullanılmıştır. Metinlerin Çok Boyutlu Okunaklılık Ölçeği ile puanlanması, araştırmacı dışında iki alan uzmanıyla birlikte yapılmıştır. Araştırma günlügünde yer alan notlardan alıntılar yapılarak uygulama sürecinin anlatımı zenginleştirilmiştir. Ayrıca günlük içerik analizine tabi tutulmuş; öğretim sürecinin değişkenleri, temel ilke ve kavramları ortaya çıkarılmıştır. Sohbet tarzı görüşmelerden elde edilen veriler katılımcının ve 
ebeveynlerinin görüşlerinin aktarılmasına ihtiyaç duyulan yerlerde kullanılmıştır.

\section{Eylem Süreci ve İşlemler}

Eylem süreci ve işlemler durum belirleme çalışmaları, eylem planının hazırlanması, eylem planının uygulanması ve okunaklılı̆̆ın gelişiminin değerlendirilmesi bölümlerinden oluşmaktadır. Bu süreçte yapılan işlemler aşağıda açıklanmaktadır.

Durum Belirleme Çalışmaları: Ali'nin yazma güçlüklerini belirleyebilmek için büyük ve küçük harflerin yazımı, metin örnekleri, çalışma kitabındaki yazıları, matematik defteri ve resim defteri incelenmiştir. Büyük harflerin (Şekil 1) ve küçük harflerin (Şekil 2) yazımını gösteren örnekler aşağıda görülmektedir:

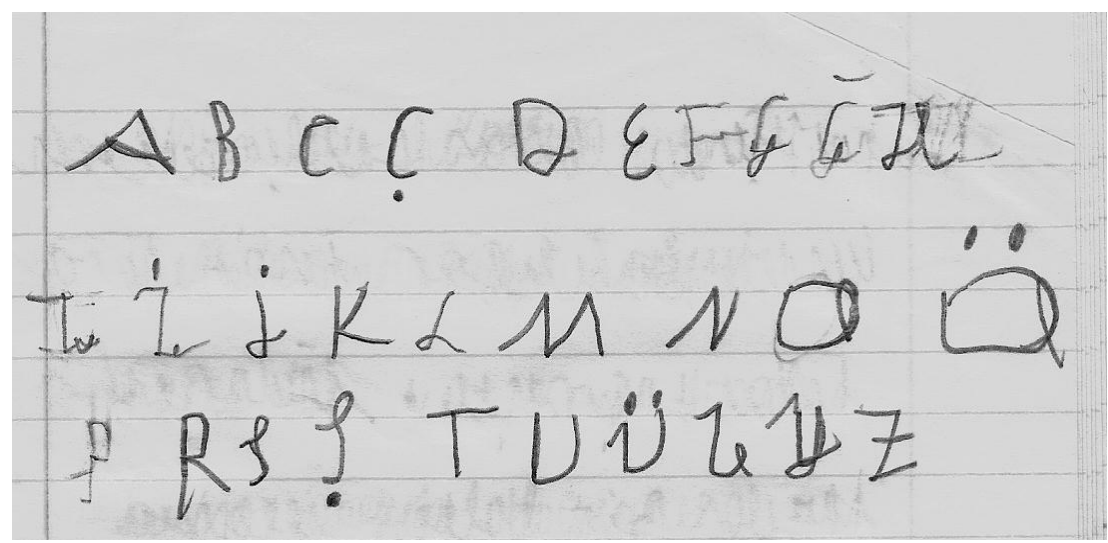

Şekil 1: Büyük Harfler

Şekil 1'de verilen büyük harfler detaylı incelendiğinde, harflerin çoğunun biçimsel olarak 'bitişik eğik yazı' stiline uygun üretilmediği görülmektedir. Örneğin A, B, C, Ç, K, M, N, R, T ve U harfleri, dik temel yazı stiline uygundur. Bitişik eğik yazı stiline benzeyen biçimsel özellikler taşıyan harflerin (örn. D, E, G, Ğ, H, I, İJ vb.) doğru yazılmadı̆̆ 1 görülmektedir. Harflerin başlama ve bitiş yerlerinin, gövde yerleştirilmelerinin, alt ve üst uzantılarının hatalı olduğu görülmektedir. Buna ek olarak çizgi takibinde sorun olduğu bazı harflerde satır çizgisinin altına inme (örn. E, P, R), bazı harflerde satır çizgisinin üstüne çıma (örn. $\mathrm{O}$, Ö, Y) hataları görülmektedir. Yukarıdaki yazı örneklerinden hareketle Ali'nin büyük harflerin hiçbirisini tam olarak doğru yazamadığı 
söylenebilir. Şekil 2' de küçük harflerin yazımı görülmektedir.

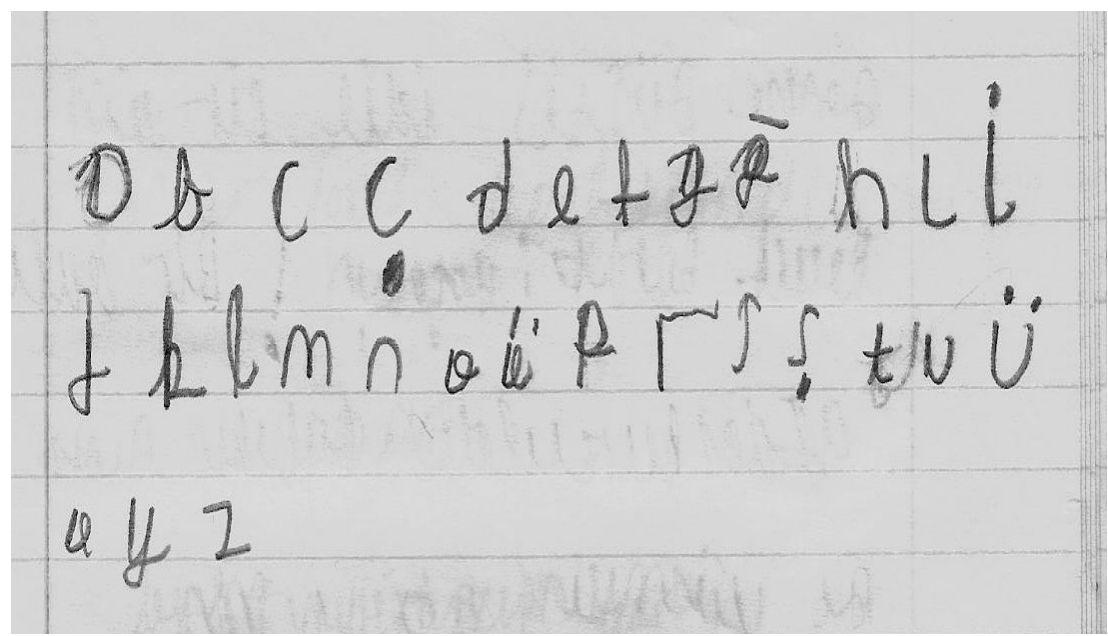

Şekil 2: Küçük Harfler

Şekil 2 incelendiğinde, küçük harflerin yazımında en dikkat çeken durumun ebat sorunu olduğu görülmektedir. Harflerin büyük çoğunluğunun iki çizginin arasına yerleştirilerek (örn. a, c, ç, ı, i, m, r, ü) olması gerekenden çok büyük yazıldığı görülmektedir. Yine büyük harflerde olduğu gibi küçük harflerin de önemli bir kısmının biçimsel olarak bitişik eğik stilinden ziyade dik temel stile uygun olduğu (örn. c, ç, m, n, ş, u, $\ddot{u}, \mathrm{z})$ söylenebilir. Ayrıca bazı harflerin ( $\mathrm{g}$, $\breve{g}$, p, s, ş) satır çizgisine konumlandırılmasında, gövdelerinin yerleştirilmesinde, alt ve üst uzantılarında ciddi sorunlar olduğu görülmektedir. Küçük harflerin yazımı genel olarak değerlendirildiğinde harflerin tamamına yakının yanlış yazıldığı söylenebilir. Ali'nin yazı performansı hakkında daha iyi karar verebilmek için Türkçe defterinde bulunan bir kopyalama (bakarak yazma) çalışması incelenmiştir. Ali'nin yazdığı metin Şekil 3'te görülmektedir.

Şekil 3'te yer alan yazı örneği incelendiğinde, küçük ve büyük harflerde tespit edilen sorunların devam ettiği hatta arttı̆̆ 1 görülmektedir. Harfler biçimsel olarak yetersizdir ve küçük harfler ebat olarak olması gerekenden çok büyüktür. Büyük harfler ve küçük harfler aynı ebatta yazılmıştır. Harflerin biçimsel olarak yetersizliğini oluşturan faktörlerin harflerin başlama ve bitiş yerleri, alt ve üst uzantıları, gövdenin yerleştirilmesi olduğu söylenebilir. Buna ek olarak bağlantılar da uygun olmayınca metin ileri derecede okunaksız bir yapıya sahip olmaktadır. 
Ali'nin yazı yazarken gözlemlenmesi sonucunda yazı bozukluğunun temel kaynağının harflerin biçimsel olarak oluşturulmasını sağlayacak hareketlerdeki eksiklikler olduğu belirlenmiştir. Ali, bitişik eğik harflerin oluşturulması için gereken hareketleri olması gereken esneklik ve aşamalarda yapamadığı görülmüştür.

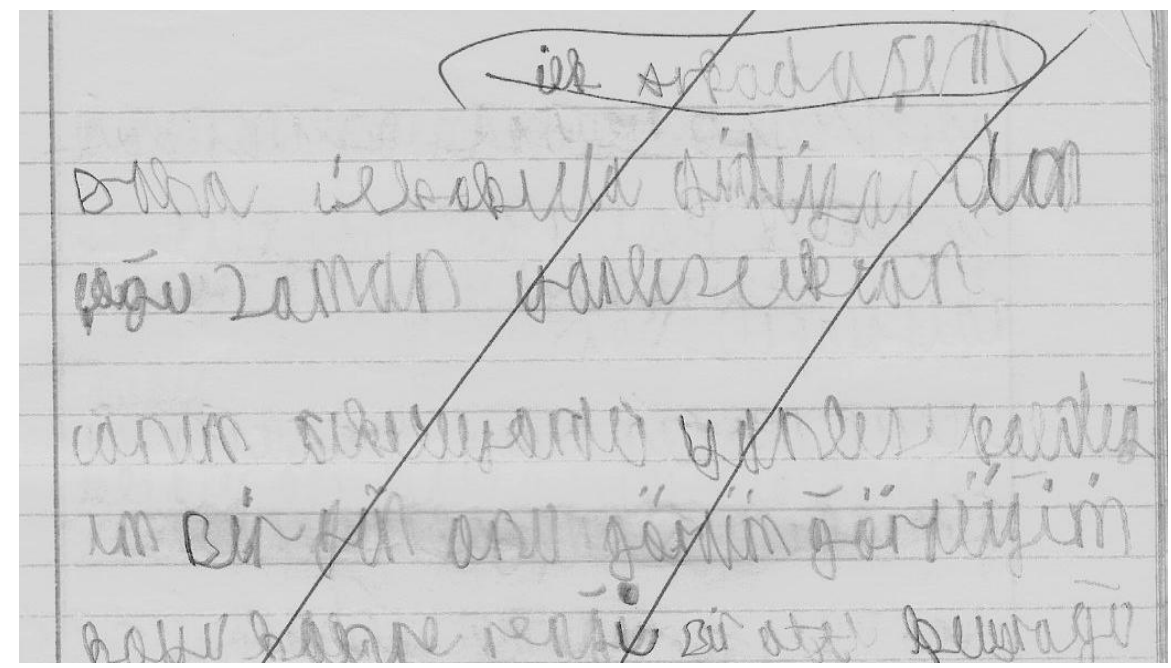

Şekil 3: Türkçe Defteri Yazı Örneği

Ali'nin harflerin doğru oluşturulması için gerekli olan ince motor hareketlerde yeterince esnek olmadığı gözlemlenmiştir. Bu durumun gelişimsel koordinasyon bozukluğu olan öğrencilerin temel özelliği olduğu bilinmektedir. Gelişimsel koordinasyon bozukluğu olan öğrencilerin temel sorunları ince motor hareketlerde güçlük yaşamalarıdır. Bu durum öğrencinin öyküsünde ulaşılan bilgilerle de örtüşmektedir.

Eylem Planının Hazırlanması: Eylem planının hazırlanma aşamasında ilk olarak okul idaresi ve ebeveynler ile görüşülerek konu aktarılmış ve öğrenciyle çalışma yapılabileceğine yönelik onayları alınmıştır. Daha sonra konu Ali'yle paylaşılmıştır. Yalpan görüşmede Ali'ye "Kendi yazından memnun musun?, Kendi yazını zorlanmadan okuyabiliyor musun?, Başkaları senin yazını okurken zorlanıyor mu?, Yazının daha güzel olmasını ister misin?" gibi sorular sorularak bu konudaki düşünceleri öğrenilmiştir. Yazısının okunaklı ve güzel olmasının kendisine ne gibi faydalarının olacağından bahsedilmiştir. Kendisi de isterse daha güzel yazabilmesi için bazı çalışmalar yapılacağı belirtilmiştir. 
Daha sonra okuma yazma güçlükleri ve yazı öğretimiyle ilgili literatür incelenmiş, alan uzmanlarıyla görüşülmüş, Ali'nin okunaklı yazma becerisini geliştirmede etkili olacak yaklaşımlar belirlenmiştir. Durum tespiti sürecinde belirlenen sorunlar dikkate alınarak Ali'ye harflerin yeniden öğretilmesi gerektiğine karar verilmiştir. Çünkü okunaklı yazma becerisinin kazandırılması için harf şekillerinin doğru olarak kavratılması gerektiği (Akyol, 2011b) belirtilmektedir. Harflerin öğretiminin yanı sıra hece, kelime, cümle ve metin yazımı çalışmaları da tasarlanmıştır. Böylece harften cümleye, cümleden metin yazımına doğru ilerleyen bir süreçte okunaklı yazmanın öğretimi hedeflenmiştir. Hazırlanan eylem planı uygulama sürecinde öğrencinin hızına, yaşadığı güçlüklere göre esnek bir yapıda uygulanmıştır.

Yazmada omuz, kol, bilek ve parmak kasları önemlidir ve kas gelişiminde büyük kaslardan küçük kaslara doğru bir yol izlenmelidir (Akyol, 2011b; Çinar-Özdemir, 2006). Ali'ye harflerin öğretiminde büyük kas hareketlerinden (omuz, kol vb.) küçük kas hareketlerine (el, parmak vb.) doğru ilerleyen aşamalandırılmış yazı öğretim süreci tasarlanmıştır. Daha sonra bu sürecin uygulanmasında ihtiyaç duyulabilecek çalışma ve etkinlikler belirlenmiştir. Uygulama sürecinde ihtiyaç duyulacak araç ve gereçlerin önemli bir kısmı (kartonlar, renkli kalemler, tahta kalemi, küçük kartlar, A4 ebadında kâğıtlar vb.) araştırmacı tarafından temin edilmiştir. Ebeveynlerden dört çizgi üç aralık sayfa yapısına sahip bir yazı defteri almaları istenmiştir.

Eylem Planının Uygulanması: Uygulama, yedi hafta boyunca her okul günü yaklaşık 30'ar dakikalık oturumlar şeklinde sürdürülmüştür. Toplamda 35 ders yapılmıştır. Uygulama sürecinde, araştırmacının yazma güçlüğü olan öğrencinin öğretmeni olmasından kaynaklana bazı esneklikler olmuştur. Eylem planı doğrultusunda yapılan çalışmalar EK 1'de sunulmaktadır. Çalışmalar bazen derslerin bitiminde sınıfta diğer öğrenciler yokken, bazen sinffta diğer öğrenciler varken uygun zamanlarda gerçekleştirilmiştir. Üçünü haftadan itibaren her haftanın cuma günü dikte ve tekrar çalışmalarına ayrılmıştır. Harflerin öğretim sürecinde öğrencinin gelişimsel özelliklerine ve sorunlarına duyarlı davranılmış, öğretim süreci aşamalandırılmışır. Bu aşamalarda yapılan etkinlikler " $\mathrm{A}$ " harfinin öğretim sürecini betimleyen görsellerle birlikte aşağıda açıklanmaktadır:

1. Büyük Karton Çalışması: Birinci aşamada, öğretilecek harf büyük kartonlara yazılarak sınıfın uygun yerine asılmıştır. Harfin yazımında 
izlenmesi gereken yol oklarla gösterilmiştir. Ali, model harfin üstünden harfin biçimini ve yazım kurallarını kavrayana kadar önce parmağıyla (Şekil 4) sonra renkli kalemlerle (Şekil 5) geçmektedir.

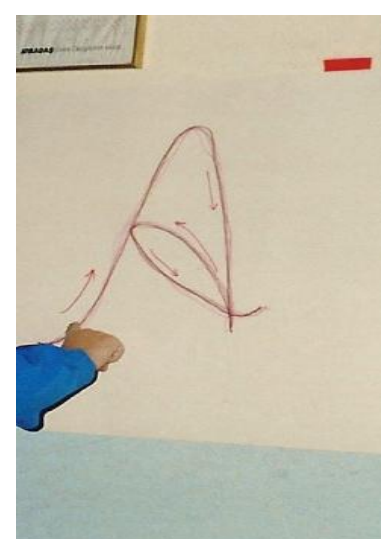

Şekil 4: Büyük Kartona Yazılı Harfin Üzerinden Parmakla Geçme

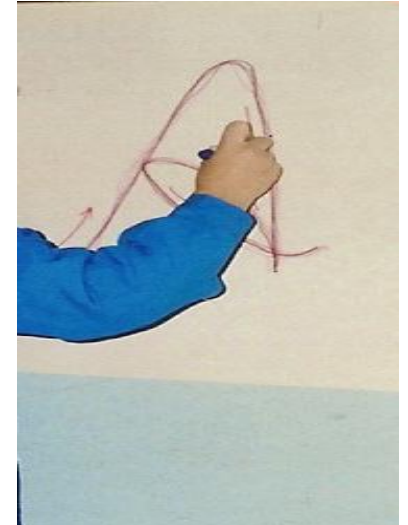

Şekil 5: Büyük Kartona Yazılı Harfin Üzerinden Renkli Kalemle Geçme

Büyük karton çalışmaları her zaman önce duvara asılı olarak başlamıştır. Ali harfin yazımıyla ilgili temel hareketleri kavradıktan sonra çalışma bazen yerde bazen öğretmen ve öğrenci masasında yapılmıştır. Böylece öğrencinin değişik pozisyonlarda omuz ve kol kaslarını kullanması sağlanmıştır. Büyük karton çalışmaları, Ali'nin harfin yazımını zihinsel olarak yeniden kodlamasına yardımcı olmuştur. Günlükten aktarılan aşağıdaki alıntı bu duruma örnek olabilir:

"Ali ile zaman zaman harfler üzerinde konuşuyoruz. Ona bir harf söyleyip bana bu harfin nasıl yazıldığını anlatmasını istiyorum. Bu çalışmaları yaparken dikkatimi çeken bir durum oldu. Ali bir yandan harfin nasıl yazılması gerektiğini sözlü olarak anlatırken dĭ̆gr yandan parmă̆ıyla harfin şeklini havaya çiziyor."

Akyol'a (2011) göre, çocuk harflerin şekillerini doğru ve hızlı olarak öncelikle zihninde canlandırabilmelidir. Ali'nin harfin yazımını sözel olarak ifade ederken görsel imajını parmağıyla oluşturması yapılan çalışmanın amacına ulaştığını göstermektedir. Bunun gerçekleşmesi çok olay olmamıştır. Uygulanan eylem planı etkinlikleri (EK 1) incelendiğinde birinci hafta boyunca yazılanların yalnızca ' $a, t, A$, at ve ata' olduğu görülmektedir. Hızlı yazdığında Ali'nin çok hata yaptığı görülmüştür. 
Bunun üzerine yavaş yazması söylenmiş ve yorulduğunda çalışmaya ara verebileceği belirtilmiştir. Süreç Ali'nin hızına göre şekillendirilmiştir.

2. Harf Çalışma Kâ̆̆ıdı: İkinci şamada harflerin 150 punto ve 50 puntoluk büyüklüklerde yazılı olduğu harf çalışma kâğıtları hazırlanmıştır (Şekil 6). Çalışma kâğıdına harfler silik olarak yazılmıştır. Ali istediği renkli kalemi kullanarak harflerin üzerinden geçmektedir (Şekil 7).

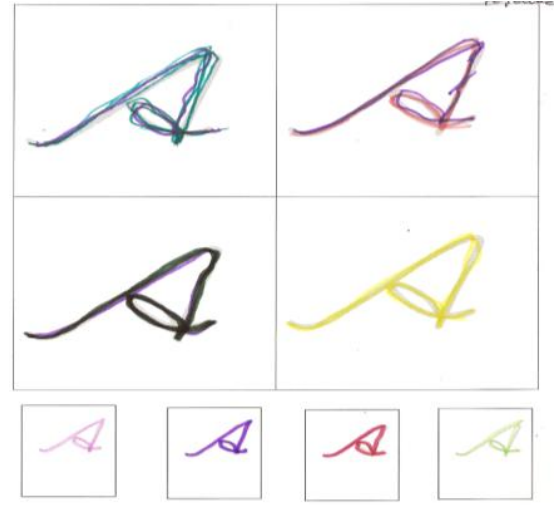

Şekil 6: Silik Yazılı 150 ve 50 Puntoluk Harflerden Oluşan Çalışma Kâğıdı

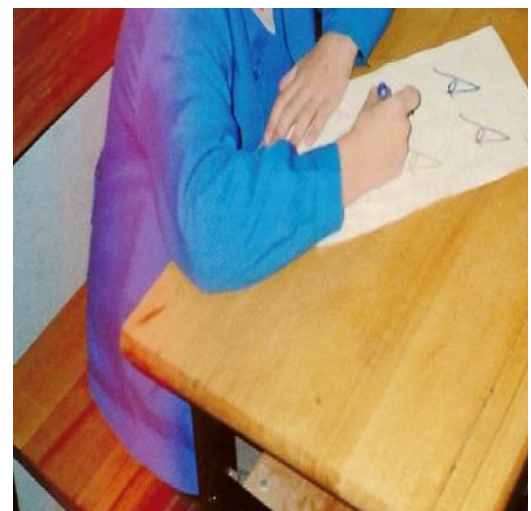

Şekil 7: Renkli Kalemlerle Silik Yazll 150 ve 50 Puntoluk Harflerin Üzerinden Geçme

Şekil 6'da görülen çalışma kâğıdının üst bölümüne yer alan harfler incelendiğinde, Ali'nin harflerin üzerinden geçerken bile çizgi takibinde zorlandığı anlaşılmaktadır. Görüldüğü gibi ilk harflerde çizgiden taşmalar olduğu daha sonraki harflerde bu sorunun azaldığı anlaşılmaktadır. Harf çalışması yapılırken Ali'nin istediği renkli kalemi kullanmasına izin verilmiştir. Bu durumun Ali'yi çalışmaya gönüllü olma konusunda motive ettiği gözlemlenmiştir. Bu çalışmalarının ardından harf, hece, kelime ve cümle yazımına yönelik etkinliklerin gerçekleştirildiği üçüncü aşamaya geçilmektedir.

3. Yapılandırılmış Çalışma Kâğıdı: Üçüncü aşama için dört çizgi üç aralıklı yazı defteri formatında düzenlenmiş üç bölümden oluşan yapılandırılmış çalışma kağıtları hazırlanmıştır. Bu aşama Ali'nin yazarken kalem kullanmasını gerektiren etkinliklerin başladığı aşamadır (Şekil 8). Bu bakımdan yapılandırılmış çalışma kâğıtlarının birinci bölümü ergonomik becerilere ilişkin farkındalık oluşturmak, ikinci bölümü bağımsız yazma becerilerini geliştirmek, üçüncü ve son bölüm ise yazılanların okunaklılık 
bakımından değerlendirilmesi amacıyla düzenlenmiştir. Bu çalışmalarla Ali'nin yazma sürecinin sorumluğunu üstlenmesi hedeflenmiştir.

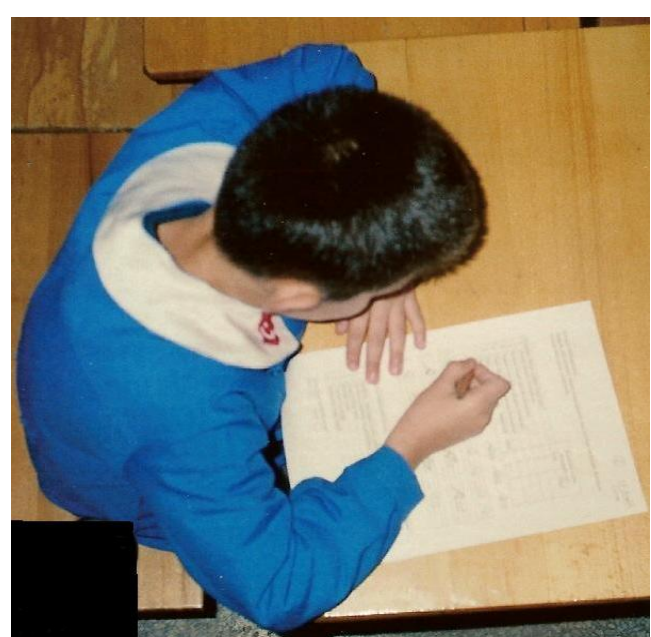

Şekil 8: Yapılandırılmış Çalışma Kâğıdı Etkinliği

Yapılandırılmış çalışma kâğıtlarının birinci bölümünde ergonomik becerilerin geliştirilmesine odaklanılmıştır. Yazmada ergonomik faktörler kalem tutma, defter/kağıt pozisyonu, yazmayan elin konumu, gövde pozisyonu gibi yazma süreciyle ilgili değişkenlerdir (Taylor, 2006). Yapılandırılmış çalışma kâğıdının birinci bölümünde (Şekil 9) yazmada etkili olan ergonomik faktörlere ilişkin farkındalık oluşturmayı amaçlayan yönerge, maddeler ve değerlendirme bölümü görülmektedir. Sevgili
Aşağıa yazı yazarken dikkat etmen gereken bazı kurallar verilmiştir. Kurallara
uyarsan daha güzel yazabilirsin.

\begin{tabular}{|c|c|c|c|}
\hline & & \multicolumn{2}{|c|}{$\begin{array}{c}\text { Kurallara uygun } \\
\text { davrandın mi? }\end{array}$} \\
\hline \multicolumn{2}{|c|}{ Yazarken Nelere Dikkat Etmelisin? } & Evet & Hayır \\
\hline 1 & Sırada düzgün oturmalısın. & $t$ & \\
\hline 2 & Kalemi uygun şekilde tutmalısın. & + & \\
\hline 3 & Kağıdı veya defteri düzgün tutmalısın. & + & \\
\hline 4 & Diğer elini masanın üzerine koymalısın. & t & \\
\hline 5 & $\begin{array}{l}\text { Elini fazla sıkmamalı, bileklerini rahat } \\
\text { hareket ettirmelisin. }\end{array}$ & $t$ & \\
\hline
\end{tabular}

Şekil 9: Yapılandırılmış Çalışma Kă̆ıdı Birinci Bölüm (Ergonomik Faktörler) 
Yapılandırılmış çalışma kâğıdının birinci bölümünde önce silik yazılmış harf (A) ve kelimelerin (Ata) üzerinden geçilmektedir. Bu görev tamamladıktan sonra yazmaya ara verilip "Yazarken nelere dikkat etmelisin?" bölümündeki maddeler okunmakta, her bir madde okunduktan sonra maddenin karşısında yer alan "Evet" ve "Hayır" seçenekleri işaretlenmektedir. Bu çalışmanın temel amacı Ali'yi kendi yazma süreci üzerinde düşündürmek ve kendini denetlemesini sağlamaktır. Aslında bu uygulama öğretim yaklaşımımız hakkında da bazı ipuçları vermektedir. Ali'ye okunaklı yazma becerisinin kazandırılma süreci basit bir ödül-ceza sistemi çerçevesinde yürütülmemiştir. Elbette öğrenciyi motive etmek için küçük ödüller söz konusu olmuştur. Ancak temelde süreç, öğrencinin kendi öğrenme sorumluluğunu üstlendiği, kendini izleyip denetlediği bir çerçevede ilerlemiştir. Birinci bölüm tamamladıktan sonra yapılandırılmış çalışma kâğıdının ikinci bölümüne (Şekil 10) geçilip araştırmacının söylediği harf, hece, kelime veya cümle yazılmaktadır.

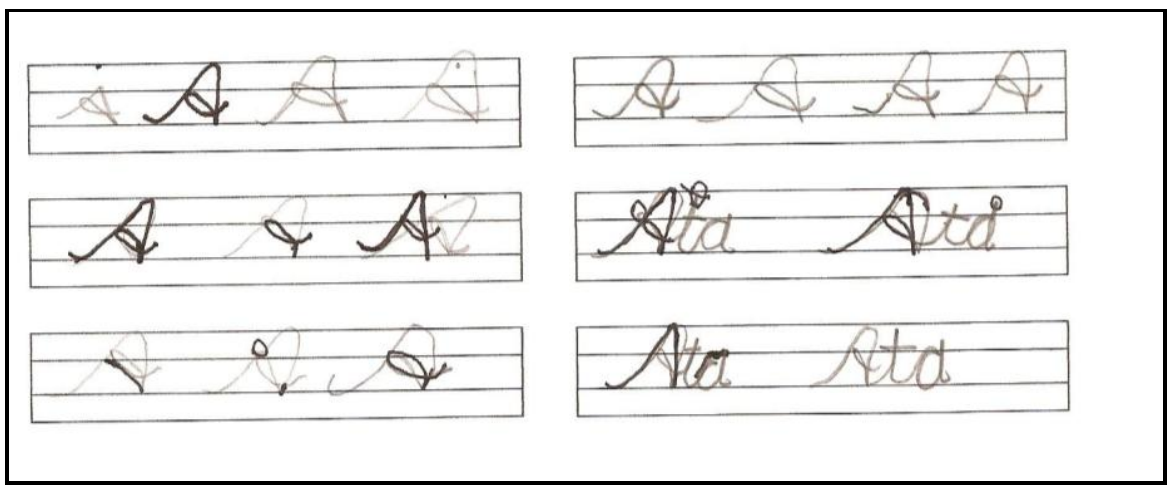

Şekil 10: Yapılandırılmış Çalışma Kağıdı İkinci Bölüm (Bağımsız Yazma)

Şekil 10'da Ali'nin bağımsız olarak yazdığı harf ve kelimeler görülmektedir. Yapılandırılmış çalışma kâğıtlarının yukarıdaki formata ulaşması da zaman almıştır. Dört çizgiden oluşan satırların orta aralığı önce $5 \mathrm{~mm}$ olarak ayarlanmıştı. Bu aralığın geniş olduğu, Ali'nin harfleri bu aralığa konumlandırmada sorun yaşadığı görülünce aralık $4 \mathrm{~mm}$ olarak düzenlenmiştir. Yapılandırılmış çâlışma kâğıtlarının son bölümü (Şekil 11) yazıların okunaklık bakımından değerlendirilmesi için düzenlenmiştir.

Ali'nin yazdıklarını okunaklılık bakımından değerlendirebilmesi için harflerin başlangıç ve bitiş yerleri, yükseklik ve genişlikleri, çizgi takibi, bağlantılar, yazının koyuluğu ve boşluktan oluşan altı ölçüt belirlenmiştir. 
Ali her bir ölçütü okumakta, yazdıklarının bu ölçüte uygunluğuna karar vermektedir.

\begin{tabular}{|c|c|c|c|c|}
\hline & Yazımı Değerlendiriyorum & Uygun & $\begin{array}{l}\text { Biraz } \\
\text { uygun }\end{array}$ & $\begin{array}{l}\text { Uygun } \\
\text { değil }\end{array}$ \\
\hline 1 & Harflerin başlangıç ve bitiş yerleri & & $t$ & \\
\hline 2 & Harflerin yükseklik ve genişlikleri & & $t$ & \\
\hline 3 & Çizgiyi takip etme & & & \\
\hline 4 & Birleştirmeler & $t$ & & \\
\hline 5 & Yazının koyuluğu & $t$ & & \\
\hline 6 & Kelimeler arası boşluk & $t$ & & \\
\hline
\end{tabular}

Şekil 11: Yapılandırılmış Çalışma Kağıdı Üçüncü Bölüm (Okunaklllığı Değerlendirme)

Araştırmacı değerlendirme sürecinde Ali'yi izlemekte, yazıların ölçütlere uygunluğunun belirlenmesine (Şekil 10' da görülen koyu yazılımlar araştırmacının yaptığı düzeltmelerdir.) rehberlik etmektedir. Değerlendirmenin ardından "Daha güzel yazabilir misin? sorusu cevaplanmakta ve yapılandırılmış çalışma kâğıdı etkinliği tamamlanmaktadır. $\mathrm{Bu}$ çalışmanın ardından dördüncü aşamaya geçilmektedir.

4. Yazı Defteri Çalışması: Aşamalandırılmış yazı öğretimi çalışmasının dördüncü ve son aşamasında dört çizgi üç aralık formatındaki yazı defterlerine geçilerek harf, kelime ve cümle yazma çalışmaları yapılmaktadır (Şekil 12).

Şekil 12 incelendiğinde yazı defteri çalışmalarında harf, hece/kelime, cümle yazımı şeklinde bir sıra izlendiği görülmektedir. İlk çalışmalarda araştırmacının örnek yazımlarıyla öğrenciye rehberlik edilmekte sonunda örenci bağımsız olarak yazmaktadır. Yazılanlar değerlendirilmekte, yapılan doğru ve yanlışlar öğrenciyle konuşulup anında dönüt verilmektedir. Bu süreçte Ali'nin yazı okunaklığında eskiye göre çok ciddi düzelmeler olduğu görülmüştür. Ali harfleri hatasız yapmaya başlamıştır. Ancak ne yapılırsa yapılsın öğrencinin ürettiği yazı standart ölçütlere uygun bir bitişik yazı olmamaktadır. Akyol'un (2011b) belirttiği gibi öğrenci yazıda kendi üslubunu oluşturuyor. 


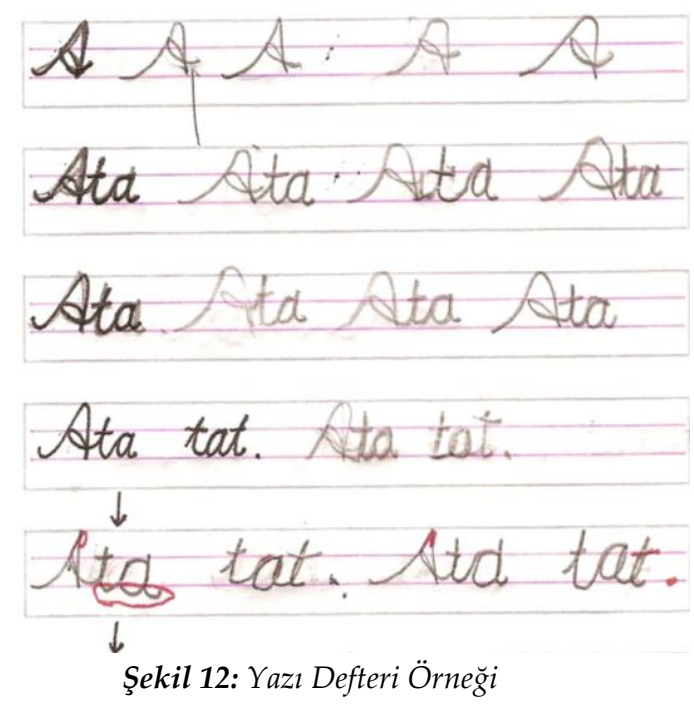

Uygulama sürecinde çalışmayı zora sokan bazı durumlar da olmuştur. Karşılaşılan örnek bir sorun ve bu soruna üretilen çözüm günlükte şu şekilde anlatılmaktadır:

"Ali derslerle ilgili yazma gerektiren ödevlerini tamamlarken alışkın olduğu harf karakterlerini kullanıyor. Uygulamamız sona erene kadar Ali'ye yazma gerektirecek ödev vermeme kararı aldım. Kararımı Ali'ye ve ebeveynlerine bildirdim."

Uygulama sürecinin beşinci haftasından itibaren Ali sınıfla birlikte yapılan yazı çalışmalarına katılmaya ve iki çizgili deftere yazmaya başlamıştır. İki çizgili deftere yazı yazmada yaşanan sorun ve bu soruna üretilen çözüm günlükte şu şekilde aktarılmaktadır:

"Iki çizgili deftere yazı yazarken harflerin ebatların ayarlamakta zorlandı. Satırın ortasına silik bir çizgi çizdim. Bu çizgi Ali'nin harflerin boyutların ayarlamasında etkili oldu."

Uygulama süresince bu şekilde pek çok küçük soruna pratik çözümler üretilmiştir. Ali ile zaman zaman sohbet edilmiş, yapılanlar hakkında düşünceleri öğrenilmiştir. Özellikle yapılandırılmış çâlışma kâğıtlarının öğrencinin yazma sürecine ilişkin farkındalığını artırarak kendinizi izleme, denetleme ve değerlendirme gibi becerilerinin gelişimine olumlu katkı sağladığı görülmüştür. Uygulama sürecinin en temel öğretim ilkelerinin, 
ödev, kontrol, tekrar, dönüt ve düzeltme olduğu söylenebilir. Ali'yi motive etme etmek için küçük ödüller (çikolata, yıldız, aferin, yapıştırmalı etiket vb.) kullanılmıştır. Süreçte ebeveynlerle sürekli iletişim halinde olunmuştur.

Uygulamanın Etkililiğinin Değerlendirilmesi: Ali'nin yazılarının okunaklılık düzeyindeki gelişimi değerlendirebilmek için uygulama öncesi ve uygulama sonrası yazı örnekleri karşılaştırılmıştır. 'Ali ile Veli' başlıklı dikte metninin uygulama öncesi (Şekil 13) ve sonrası (Şekil 14) yazımı aşağıdaki gibidir:

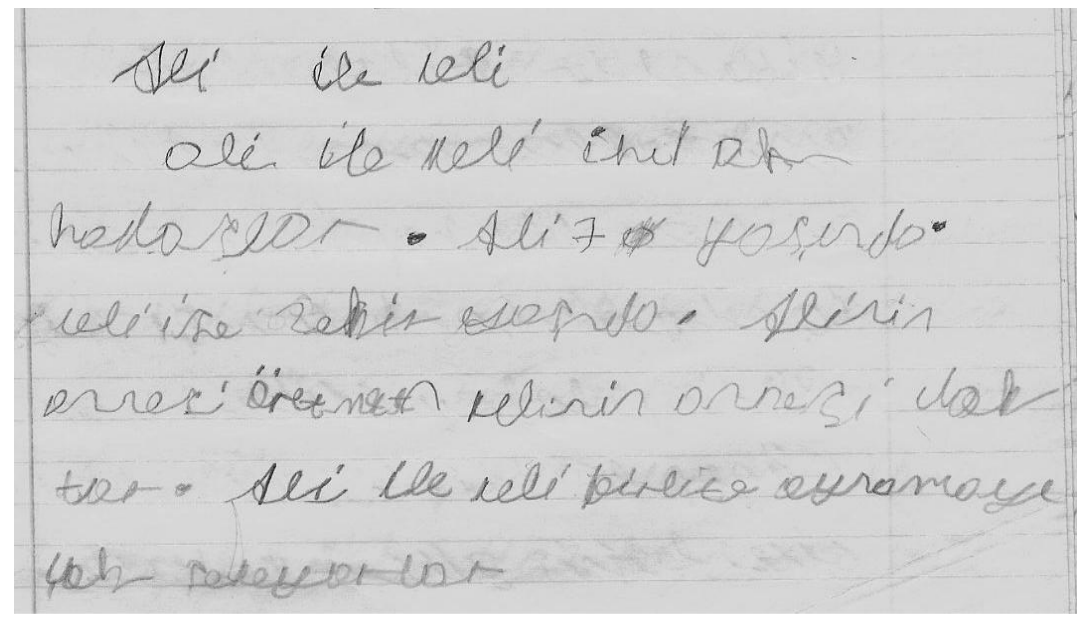

Şekil 13: Uygulama Öncesi Dikte Çalışması (Ali ile Veli)

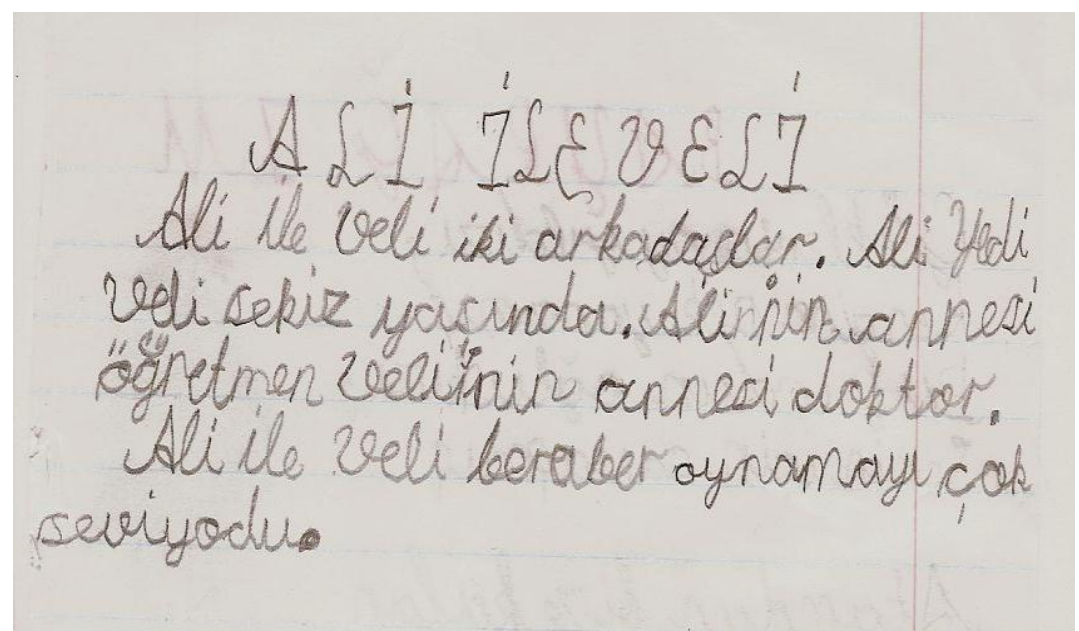

Şekil 14: Uygulama Sonrası Dikte Çalışması (Ali ile Veli) 
Uygulama öncesi dikte metni incelendiğinde biçim bakımından yetersiz (1 puan), ebat bakımından yetersiz (1 puan), boşluk bakımından yetersiz (1 puan) eğim bakımından yetersiz (1 puan), çizgi takibi bakımından kısmen yeterli (2 puan) olduğu görülmektedir. Ölçekten alınan toplam puan 6 'dır. Bu durum uygulama öncesi dikte metninin okunaklılık bakımından yetersiz olduğunu göstermektedir.

Uygulama sonrası dikte metni incelendiğinde biçim orta düzeyde yeterli (2 puan), ebat bakımından yeterli (3 puan), boşluk bakımından yetersiz (1 puan) eğim bakımından orta düzeyde yeterli (2 puan), çizgi takibi bakımından kısmen yeterli (2 puan) olduğu görülmektedir. Ölçekten alınan toplam puan $10^{\prime}$ dur. Bu durum uygulama sonrası dikte metninin orta düzeyde okunaklı olduğunu göstermektedir.

'Bayrağım' şiirinin uygulama öncesi (Şekil 15) ve sonrası (Şekil 16) kopyalama şeklindeki yazımı aşağıdaki gibidir:

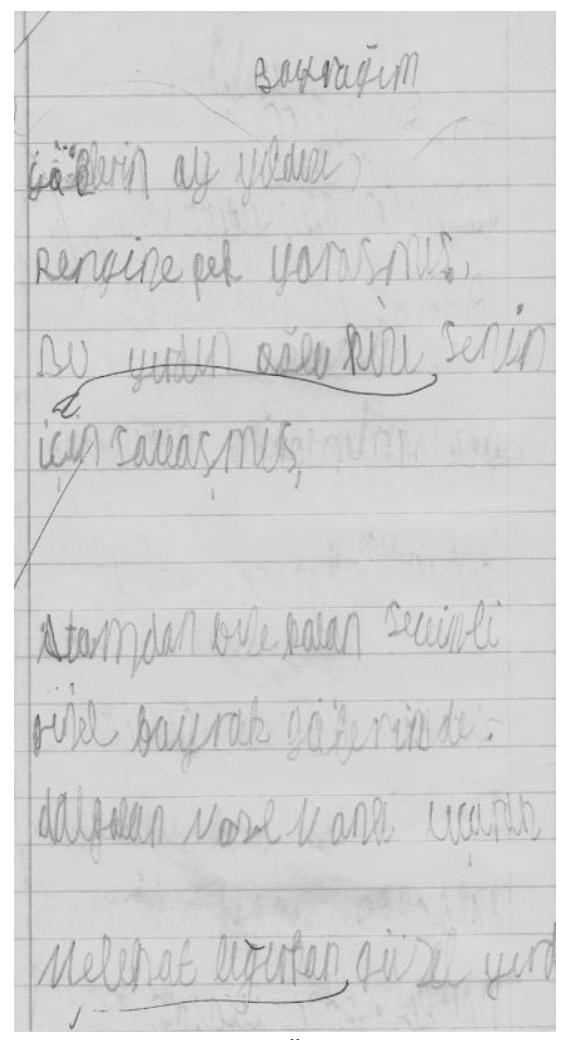

Şekil 15: Uygulama Öncesi Kopyalama

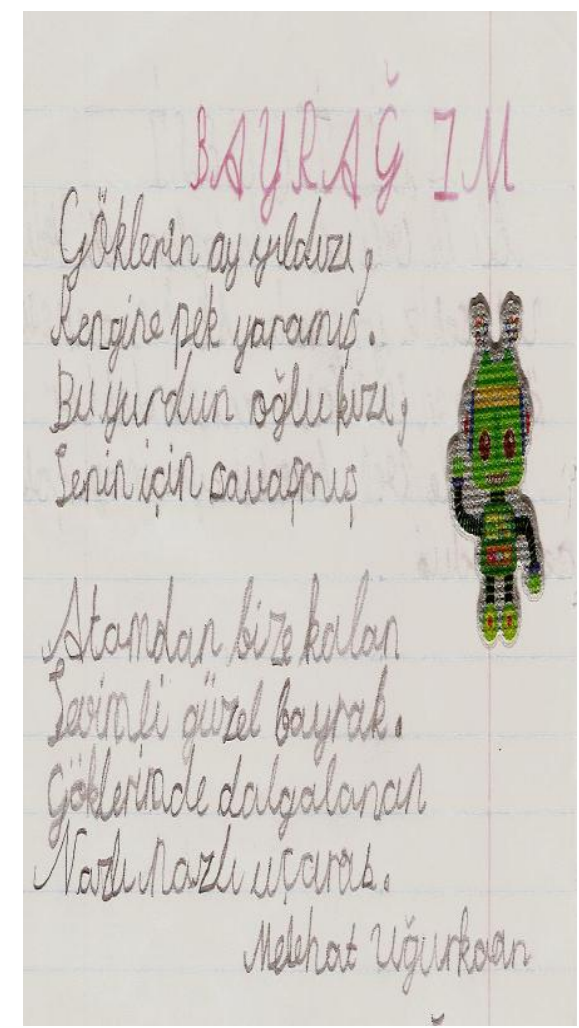

Şekil 16: Uygulama Sonrası Kopyalama 
Uygulama öncesi kopyalama metni incelendiğinde biçim bakımından yetersiz (1 puan), ebat bakımından yetersiz (1 puan), boşluk bakımından yetersiz (1 puan) eğim bakımından yetersiz (1 puan), çizgi takibi bakımından kısmen yeterli (2 puan) olduğu görülmektedir. Ölçekten alınan toplam puan 6 'dır. Bu durum uygulama öncesi kopyalama metninin okunaklılık bakımından yetersiz olduğunu göstermektedir. Uygulama sonrası kopyalama metni incelendiğinde biçim orta düzeyde yeterli (2 puan), ebat bakımından yeterli (3 puan), boşluk bakımından yetersiz (1 puan) eğim bakımından orta düzeyde yeterli (2 puan), çizgi takibi bakımından yeterli (3 puan) olduğu görülmektedir. Ölçekten alınan toplam puan 11'dir. Bu durum uygulama sonrası kopyalama metninin orta düzeyde okunaklı olduğunu göstermektedir.

\section{Sonuç ve Tartışma}

Yedi hafta süren uygulama sonunda eylem süreci tamamlanmış ve Ali orta düzeyde okunaklı bir el yazısına kavuşmuştur. Çalışmanın tasarımı ve yöntemi dikkate alındığında ulaşılan sonuçlar kadar eylem sürecinin de tartışılması gerekmektedir. Araştırma günlügünün analizi sonucunda eylem sürecini katılımol (öğrenci), araştırmacl (öğretmen), ebeveyn (anne/baba), farkındalık (kendini izleme, kendini denetleme, kendini değerlendirme), motivasyon (ilgi, gayret, ödül anlamlı bulma), beceri öğretimi (harfler, okunaklllk, büyük/küçük kas hareketleri), öğretim ilkeleri (tekrar, ödev, kontrol, dönüt/düzeltme) ve akranlar (sınıf arkadaşları) olmak üzere sekiz temel değişkenden oluştuğu belirlenmiştir. Tüm değişkenler eylem sürecinin bir boyunu oluşturmakta ve süreçte bir anlam ifade etmektedir. Bir öğrencinin yazma güçlüğünün giderilmesine yönelik olarak tasarlanan bir eylem araştırması yalnızca araştırmacı ve katılımcı arasında gerçekleşen tek boyutlu bir süreç değildir. Aksine bilişsel, duyuşsal, sosyal ve psikolojik pek faktörün eşzamanlı olarak işlediği çok boyutlu bir süreçtir. Bu eylem araştırması tasarlanıp planlanırken çok boyutluluk dikkate alınmış, değişkenler mümkün olduğunca önceden belirlenmiş ve değişkenlerin sürece olumlu katkı sağlaması için gereken önlemler alınmıştır. Süreç içerisinde gelişen ve şekillenen durumlara karşı hassas olunmuş, karşılaşılan sorunlara pratik çözümler üretilmiştir.

Yazının mekaniğinde yaşanan ve okunaklı bir yazı üretilmesini güçleştiren durumlar öğrencilerin pek çok alanda sorun yaşamasına neden olduğu bilinmektedir (Berninger ve Graham, 1998; Berninger ve Hooper, 2006; Graham, 1990; Jones ve Christensen,1999). Bu açıdan düşünüldüğünde 
okunaklı bir yazıya sahip olmalarının öğrencilere düşüncelerini yazılı olarak ifade etmede, ödevlerde, sınavlarda, performans ve proje çalışmalarında, okul çalışmalarının gerektirdiği diğer görevleri tamamlamalarında kolaylık sağlayacağı söylenebilir. Yazma güçlüklerinin giderilmesinde öğrencilerin ek bir desteğe ve müdahaleye ihtiyaç duyduğu belirtilmektedir (Feder ve Majnemer, 2007). Yazma güçlüğü olan öğrencilere uygun müdahale yaklaşımlarının belirlenebilmesi disgrafinin neden ve sonuçlarının iyi bilinmesi ile mümkündür. Disgrafi çoğunlukla ince motor becerilerinde, harflerin görselleştirilmesinde ve harflerin oluşturulması için gerekli olan motorsal süreçlerde yaşanan güçlüklerin birleşmesiyle oluşan karmaşık bir yapıdır (Akyol, 2011a). Bu çocuklar motor planlamada ve ince motor becerilerini kontrol etmede güçlük yaşarlar. El göz koordinasyonunda yaşadıkları sorunlar harflerin üretilmesinde ihtiyaç duyulan doğru hareketlerin yapılmasını güçleştirir (Taylor, 2006). Bu açıdan düşünüldüğünde, disgrafili öğrencilere okunaklı yazma becerisini kazandırabilmek için öncelikle harflerin doğru üretilmesi sağlamak gerekmektedir. Çalışmada bu ilkeden hareket edilmiş ve büyük kas hareketlerinden küçük kas hareketlerine doğru aşamalandırılmış bir yazı öğretim süreci izlenerek harf öğretimi gerçekleştirilmiştir. Bu müdahale yaklaşımı başarılı olmuş ve öğrencinin yazı okunaklılığı geliştirilmiştir.

Disgrafili öğrencilere yazı öğretimi süreci yalnızca yazma becerilerini öğretimi ya da kas geliştirme çalışmaları olarak sınırlandırılmamalıdır. Bu süreçte yazma güçlüğü yaşayan çocuğun yeni becerileri kazanmasını kolaylaştıracak ve çocuğun sürece uyumunu sağlayacak önlemler alınmalıdır. Richard (1999) bu önlemlerden bazılarının; yazı stili konusunda tercihin öğrenciye bırakılması, anında dönüt verme, kısa yazma çalışmaları, yazma görevlerini tamamlamak için daha fazla zaman verme, bilgisayar ve diğer elektronik araçların kullanılması olduğunu belirtmektedir. Çalışmada bu ilkelerden anında dönüt verme, kısa yazı çalışmaları ve yazma görevleri için yeterli zaman verme konusunda hassas olunmuştur. Bunlara ek olarak öğrencinin kendini izleme, değerlendirme ve denetleme becerileri geliştirilmeye odaklanılmış, yazma sürecine yönelik farkındalığı artırılmıştır.

Disgrafili öğrencilere müdahale süreçleri çoklu duyusal etkinlikleri, aşamalı paragraf yazma teknikleri, kalem tutma ve diğer ergonomik becerilerin öğretilmesini de içermektedir (Richard, 1999). Çalışmada öğrencinin kalem tutma, oturuş, beden pozisyonu, el pozisyonu gibi ergonomik faktörleri doğru bir şekilde kazanması için çalışmamalar 
yapılmıştır. Ergonomik faktörler yazmayı etkileyen unsurlar arasında gösterilmektedir (Akyol, 2011b; Taylor, 2006). Yazmada etkili olan ergonomik becerilerin kazandırılmasına yönelik çalışmaların öğrencinin okunaklı yazma becerisinin gelişimine olumlu bir etkiye sahip olduğu düşünülmektedir. $\mathrm{Bu}$ araştırmanın konuyla ilgili daha önce yapılmış araştırmalarla (Çinar-Özdemir, 2006; Calp, 2013) ortak bazı sonuçları olduğu söylenebilir. Yazma güçlüklerini giderilmesinde durum tespiti, duruma ya da yaşana güçlüğe uygun çalışmalar ve öğrenciyle yakından ilgilenmek gerektiği söylenebilir.

\section{Öneriler}

Yazma güçlügüne sahip olan öğrencilerin oranının \%10 ile \%34 arasında değiştiği belirtilmektedir (Smits-Engelsman, Niemeijer ve Van Galen, 2001; Smits-Engelsman, Van Galen ve Michels, 1995). Bu oranlar ilköğretimde on milyondan fazla öğrencisi olan Türkiye açısından düşünüldüğünde milyonlarla ifade edilebilecek sayıda öğrencinin yazma güçlügüne sahip olabileceğini göstermektedir. Türkiye'de yazma güçlüğü olan öğrencilerin tespiti, yazı performansları, sorun yaşadıkları alanlar ve bu sorunların giderilmesine yönelik geniş çaplı araştırmalara ihtiyaç olduğu söylenebilir. İlk yıllarda görülebilecek el yazısı güçlüklerinin daha sonra görülebilecek olan öğrenme güçlüklerinin belirtisi olabileceği ifade edilmektedir (Rosenblum, Weis ve Parush, 2003). Bu durum yazma güçlüklerinin erkenden tespit edilerek öğrencilerin dezavantajlı bir duruma düşmelerini engelleyecek önlemlerin alınması gerektiğini ortaya koymaktadır.

Yazma güçlüklerinin tespiti ve giderilmesine yönelik çalışmalarda öğretmenler ve bu konuda yetişmiş uzmanlar görev almalıdır. Öğretmenlerin bilgi, beceri, deneyim ve çalışma şartlarının okuma yazma güçlügüne sahip olan öğrencilere destek olma konusunda yeterli olmadığı bilinmektedir (Yıldız, Yıldırım, Ateş ve Rasinsky, 2012). Daha önce yapılan çalışmalar (örn. Ateş, Yıldırım ve Yıldız, 2010) öğretmenlerin okuma yazma güçlüklerinin giderilmesine yönelik konularda kendilerini yeterli görmediklerini göstermektedir. Türkiye'de okuma yazma güçlüklerinin giderilmesi konusunda okuma uzmanlarına ihtiyaç olduğu anlaşılmaktadır. Okuma uzmanları, okuma yazma güçlüklerinin tespit edilmesinde ve giderilmesinde görev alan uzmanlardır (International Reading Assocation [IRA], 2010). Öğretmenlerin okuma yazma güçlüklerinin giderilmesine yönelik beceri kazanmalarının mevcut hizmet içi eğitim programlarıyla 
sağlanması mümkün değildir. Öğretmenlerin okuma yazma güçlükleri konusunda uzmanlaşabilmeleri için okuma yazmanın doğası, değerlendirilmesi, geliştirilmesi, araştırma teknikleri vb. konularında iyi yetiştirilmeleri gerekmektedir. Bu da ancak yüksek lisans ve uzun süreli sertifika programlarıla mümkün olabilir. Akyol ve Yıldız'ın (2013) vurguladığı gibi Türkiye'de vakit kaybedilmeden bu programların açılması ve yaygınlaştırılması gerekmektedir.

Çalışmanın bir eylem araştırması olmasından kaynaklana bazı önerilere de yer verilebilir. Eylem araştırmaları, öğretmenler (ya da eğitim ortamındaki diğer bireyler) tarafından öğrencilerinin öğrenmeleri, kendi öğretimleri ve eğitim ortamındaki özel durumları daha iyi anlamaları ve geliştirmeleri için yürütülen sistematik çalışmalardır (Mills, 2000). Öğretmenlerin sınıflarında karşılaştıkları problemlere çözüm üretmeleri, günümüzde okulların kendini yenilemesi süreci açısından büyük bir öneme sahiptir (Creswel, 2005). Bu açıdan düşünüldügünde öğretmenler sinıflarında yazma güçlüğü olan öğrencilerin sorunlarını gidermeye yönelik eylem planları hazırlayıp uygulamaya teşvik edilmelidir. Bunun için eylem araştırmaları ya da diğer bir adıyla öğretmen araştırmaları öğretmen yetiştirme programlarında mutlaka ders olarak yer bulmalıdır. Öğretmenlerin eylem araştırmaları konusunda yetiştirilebilmeleri için hizmet içi eğitim imkânları da kullanılmalıdır.

$\mathrm{Bu}$ araştırmada yazma güçlüğü olan bir öğrencinin el yazısı okunaklılığı geliştirilmeye ve bu sürecin betimlenmesine odaklanıldı. Bundan sonra yapılacak çalışmalarda yazma güçlüğü olan öğrencilerin yazım hatalarının giderilmesi, yazılı anlatım becerilerinin geliştirilmesi, bu öğrencilere metin türlerine (öyküleyici ve bilgi verici metin) yönelik ürün oluşturma becerisinin kazandırılmasına yönelik çalışmalar yapılabilir. Buna ek olarak yazma güçlüklerinin giderilmesinde etkili olduğu belirlenmiş strateji, yöntem, teknik ya da programların etkiliğinin sınanmasına yönelik araştırmalar tasarlanabilir.

\section{Yazarın Notu}

Bu çalışma, 11. Ulusal Sınıf Öğretmenliği Sempozyumu'nda sunulan sözlü bildirinin yeniden yapılandırılmış şeklidir. Fotoğraflarının makalede kullanılmasına izin verdikleri için öğrencime ve ebeveynlerine teşekkür ederim. 


\section{Kaynakça}

Akyol, H. (Mart, 2011a). Disgrafi . Eğitimci Öğretmen Dergisi, 1, 8-11.

Akyol, H. (2011b). Türkçe ilk okuma yazma öğretimi (10. Baskı). Pegem: Ankara.

Ateş, S., Yıldırım, K., \& Yıldız, M. (2010). Opinions of classroom teachers and prospective classroom teachers about the learning difficulties encountered in the teaching process of reading and writing. Ilköğretim Online, 9(1), 44-51.

Akyol, H., \& Yıldız, M. (2013). Okuma uzmanlığı ve okuma uzmanı yetiştirilmesine yönelik bir program önerisi. Okuma Yazma Ĕ̆itimi Araştırmaları, 1(1), 1-8.

Berninger, V. W., \& Graham, S. (1998). Language by hand: A synthesis of a decade of research on handwriting. Handwriting Review, 12, 11-25.

Berninger, V. W., \& Hooper, S. R. (2006). Introduction to special issue on writing. Development Neuropsychology, 29(1), 1-4.

Calp, M. (2013). Yazma problemi olan bir öğrenciye bitişik eğik yazı öğretimi (Bir eylem araştırması). E-İnternational Journal of Educatinal Research, 4(1), 1-28.

Cermak, S. (1985). Developmental dyspraxia. In E. Roy (Ed.), Advantages in psychology. Vol. 23: Neuropsychological studies of apraxia and related disorders (pp. 225-248). New York: North Holland.

Cratty, B.J. (1994). Clumsy child syndromes, descriptions, evaluation and remediation (pp. 143-144). USA: Harwood Academic.

Creswell, J. W. (2005). Educational research: Planning, conducting, and evaluating quantitative and qualitative research. Upper Saddle River, NJ: Merrill/Prentice Hall.

Çinar-Özdemir, Ö. (2006). Disgrafi problemi olan çocuklarda üst ekstremite motor eğitiminin yazı yazma üzerine etkisi. Yayımlanmamış yüksek lisans tezi, Abant İzzet Baysal Üniversitesi, Bolu.

Dennis, J.L. \& Y. Swinth (2001). Pencil grasp and children's handwriting legibility during different length writing tasks. The American Journal of Occupational Therapy, 55, 171-183.

Diagnostic and Statistical Manual of Mental Disorder-IV-TR, [DSM-IV-TR], (2007). Ruhsal bozukluklar tanısal ve sayımsal el kitabı. Dördüncü baskı 
yeniden gözden geçirilmiş tam metin, Köroğlu, E. (çeviri ed) Amerikan Psikiyatri Birliği, Washington DC, 2000. Ankara: Hekimler Birliği Yayınları.

Ediger, M. (2001). Assessing handwriting achievement. ERIC Document Reproduction Service No. ED 346082.

Engel-Yeger, B., Nagauker-Yanuv, L., \& Rosenblum, S. (2009). Handwriting performance, self-reports, and perceived self-efficacy among children with dysgraphia. American Journal of Occupational Therapy, 63, 182-192.

Erhardt, R., \& Meade, V. (2005). Improving handwriting without teaching handwriting: The consultative clinical reasoning process. Australian Occupational Therapy Journal, 52, 199-210.

Feder, K. P., \& Majnemer, A. (2007). Handwriting development, competency, and intervention. Development Medicine and Child Neurology, 49, 312-317.

Graham, S. (1990). The role of production factors in learning disabled students' compositions, Journal of Educational Psychology, 82, 781-791.

Graham, S. \& N.Weintraub (1996). A review of handwriting research: Progress and prospects from 1980-1994. Educational Psychology Review, $8,7-86$.

Graham, S., K.R. Harris \& B. Fink (2000). Is handwriting causally related to learning to write? Treatment of handwriting problems in beginning writers. Journal of Educational Psychology, 92, 620-633.

Graham, S., Harris, K.R., \& Larsen, R. (2001). Prevention and intervention of writing difficulties for students with learning disabilities. Learning Disabilities Research ve Practice, 16(2), 74-84.

Graham, S., Struck, M., Santoro, J., \& Berninger, V. W. (2006). Dimensions of good and poor handwriting legibility in first and second graders: Motor programs, visual-spatial arrangement, and letter formation parameter setting. Developmental Neuropsychology, 29, 43-60.

Hamstra-Bletz, L., \& Blote, A. (1993). A longitudinal study on dysgraphic handwriting in primary school. Journal of Learning Disabilities, 26, 689699.

International Reading Assocation [IRA]. (2010). What reading educators need to know. Reading Today, 28, 1, August/September, 12-13. 
Johnson, D.J. (1995). An overview of learning disabilities: Psychoeducational perspectives. Journal of Child Neurology, 10, S2-S8.

Jones, D. \& C.A. Christensen (1999). Relationship between automaticity in handwriting and student's ability to generate written text. Journal of Educational Psychology, 91, 44-49.

Kemmis, S., \& McTaggart, R. (2000). Participatory action research. In Denzin, N. K.\&Lincon, Y.S. (Ed.), Handbook of qualitative research (2 nd Edt), ( $p$. 567-606). Thousand, CM.Yfornia: Sage Publication.

Laszlo, J.I. (1990). Child perceptuo-motor development: Normal and abnormal development of skilled behaviour. In C.A. Hauert (Ed.), Developmental psychology: Cognitive, perceptuo-motor and neurophysiological perspective (pp. 273-308). Amsterdam: North Holland.

Laszlo, J.I., P.J. Bairstow \& J. Bartip (1988). A new approach to treatment of perceptuo-motordysfunction: previously called clumsiness. Support for Learning, 3, 35-40.

Marr, D., \& Cermak, S. (2001). Consistency of handwriting development in the early elementary years: A literature review. The Israel Journal of Occupational Therapy, 10, E109-E129.

May-Benson, T., Ingolia, P., \& Koomar, J. (2002). Daily living skills and developmental coordination disorder. In S. A. Cermak \& D. Larkin (Eds.), Developmental coordination disorder (pp. 140-156). Albany, NY: Delmar.

McHale, K. \& S.A. Cermak (1992). Fine motor activities in elementary school: Preliminary findings and provisional implications for children with fine motor problems. American Journal of Occupational Therapy, 46, 898892.

Mills, G. E. (2000). Action research A guide fort the teacher researcher. Upper Saddle River, NJ: Merrill/Prentice Hall.

Richards, R. G. (1999). Strategies for dealing dysgraphia. http://www.ldonline.org adresinden 13. 04.2013 tarihinde ulaşılmıştır.

Rosenblum, S., Weiss, P. L., \& Parush, S. (2003). Product and process evaluation of handwriting difficulties: A review. Educational Psychology Review, 15, 41-81. 
Rosen Rosenblum, S., Weiss, P. L., \& Parush, S. (2004). Handwriting evaluation for developmental dysgraphia: Process versus product. Reading and Writing, 17, 433-458.

Rosenblum, S., Aloni, T., \& Josman, N. (2010). Relationships between handwriting performance and organizational abilities among children with and without dysgraphia: A preliminary study. Research in Developmental Disabilities, 31, 502-509.

Rubin, N.\& S.E.Henderson (1982). Two sides of the same coin: Variation in teaching methods and failure to learn to write. Special Education: Forward Trends, 9, 17-24.

Taylor, J. (2006). Developing handwriting skills. In M. Snowling ve J. Stackhouse (Eds.), Dyslexia, speech and language: A practitioner's handbook (2nd Edition) (pp. 229 - 252). London: Whurr Publishers.

Smits-Engelsman, B. C. M., Niemeijer, A. S., \& Van Galen, G. P. (2001). Fine motor deficiencies in children diagnosed as DCD based on poor grapho-motor ability. Human Movement Science, 20, 161-182.

Sovik, N., Arntzen, O., \& Karlsdottir, R. (1993). Relationship between writing speed and some parameters in handwriting. Journal of Human Movement Studies, 25, 133-150.

Waber, D.P. \& J.H. Bernstein (1994). Repetative graphomotor output in L.D. and nonlearning - disabled children. The Repeated Patterns Test. Developmental Neuropsychology, 10, 51-65.

Yıldırım, A., \& Şimşek, H. (2005). Sosyal bilimlerde nitel araştırma yöntemleri. Ankara: Seçkin.

Yıldız, M., \& Ateş, S. (2007). İlköğretim 3. sınıf öğrenci yazılarının okunaklılık bakımından incelenmesi. I. Ulusal İlköğretim Kongresi'nde sunulan bildiri, Hacettepe Üniversitesi, Ankara.

Yıldız, M., Yıldırım, K., Ateş, S., \& Rasinsky, T. (2012). Perceptions of Turkish parents with children identified as dyslexic about the problems that they and their children experience, Reading Psychology, 33(5), 399-422. 


\section{EK 1. UYGULAMA PLANI VE ÇALIŞMALAR}

\begin{tabular}{|c|c|c|c|}
\hline Hafta & Ders & Etkinlik & Süre \\
\hline \multirow{5}{*}{$\begin{array}{l}\underset{ت}{\mathbb{Z}} \\
\text { ت } \\
\text { ت }\end{array}$} & 1. Ders & Materyaller tanitıldı. "a” harfi yazıldı. & $30 \mathrm{dk}$ \\
\hline & 2. Ders & "A" harfi yazıldı. "a" harfi tekrar edildi. & $30 \mathrm{dk}$ \\
\hline & 3. Ders & "t" harfinin yazımı. "A" ve "a" harflerinin tekrarı. & $30 \mathrm{dk}$ \\
\hline & 4. Ders & Harf, hece ve kelime (“A - at - ata”) yazıld1. & $30 \mathrm{dk}$ \\
\hline & 5. Ders & Tekrar ve hatasiz yazma $(\mathrm{A}-\mathrm{a}-\mathrm{at}-\mathrm{ata}-\mathrm{ata})$. & $40 \mathrm{dk}$ \\
\hline \multirow{5}{*}{ 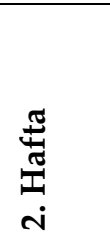 } & 6. Ders & "a" ve "t" tekrar edildi. “T, Talat" yazıldı. & $30 \mathrm{dk}$ \\
\hline & 7. Ders & “E” ve “ 1 " harflerinin yazımı. Tekrar. & $30 \mathrm{dk}$ \\
\hline & 8. Ders & “e, el, elle" yazıldı. Tekrar. & $30 \mathrm{dk}$ \\
\hline & 9. Ders & "L"yazıld1. "e" ve “l” tekrar. Dikte ve hata analizi. & $40 \mathrm{dk}$ \\
\hline & 10. Ders & “ュ” ve “i” yazıldı. Öğrenilenler tekrar edildi. & $30 \mathrm{dk}$ \\
\hline \multirow{5}{*}{$\begin{array}{l}\underset{ \pm}{ \pm} \\
\underset{ت}{I} \\
\dot{m}\end{array}$} & 11. Ders & "n" ve “N" harfi yazıldı. Hece, kelime ve cümle yazımı. & $30 \mathrm{dk}$ \\
\hline & 12. Ders & “I” ve “方” yazıldı. Hece, kelime ve cümle çalışması. & $30 \mathrm{dk}$ \\
\hline & 13. Ders & “m” ve “M" yazıldı. Hece, kelime ve cümle çalışması. & $40 \mathrm{dk}$ \\
\hline & 14. Ders & “r” ve “R” yazıldı. Hece, kelime ve cümle çalışması. & $30 \mathrm{dk}$ \\
\hline & 15. Ders & Dikte çalışması ve hata analizi. Tekrar. Ödevlendirme. & $40 \mathrm{dk}$ \\
\hline \multirow{5}{*}{ 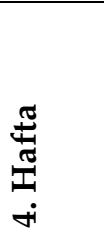 } & 16. Ders & “ö” ve “ö” yazıldı. Hece, kelime ve cümle çalışması. & $30 \mathrm{dk}$ \\
\hline & 17. Ders & “u” ve “U” yazıldı. Hece, kelime ve cümle çalışması. & $30 \mathrm{dk}$ \\
\hline & 18. Ders & “ü” ve “ن̈” yazıldı. Hece, kelime ve cümle çalışması. & $30 \mathrm{dk}$ \\
\hline & 19. Ders & “০” ve “○” yazıldı. Hece, kelime ve cümle çalışması. & $30 \mathrm{dk}$ \\
\hline & 20. Ders & Dikte çalışması ve hata analizi. Tekrar. Ödevlendirme. & $40 \mathrm{dk}$ \\
\hline \multirow{5}{*}{ 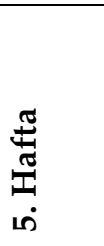 } & 21. Ders & “Y” ve “Y” yazıldı. Hece, kelime ve cümle çalışması. & $30 \mathrm{dk}$ \\
\hline & 22. Ders & “k” ve “K” yazıldı. Hece, kelime ve cümle çalışması. & $30 \mathrm{dk}$ \\
\hline & 23. Ders & “s" ve "S" yazıldı. Hece, kelime ve cümle çalışması. & $30 \mathrm{dk}$ \\
\hline & 24. Ders & “ş" ve “Ş" yazıldı. Hece, kelime ve cümle çalışması. & $30 \mathrm{dk}$ \\
\hline & 25. Ders & Dikte çalışması ve hata analizi. Tekrar. Ödevlendirme. & $40 \mathrm{dk}$ \\
\hline \multirow{5}{*}{$\begin{array}{l}\underset{ \pm}{\mathbb{Z}} \\
\underset{\mathbb{Z}}{\mid} \\
\dot{0}\end{array}$} & 26. Ders & “d” ve “D” yazıldı. Hece, kelime ve cümle çalışması. & $30 \mathrm{dk}$ \\
\hline & 27. Ders & “b” ve “B”yazıldı. Hece, kelime ve cümle çalışması. & $30 \mathrm{dk}$ \\
\hline & 28. Ders & “z” ve “Z” yazıldı. Hece, kelime ve cümle çalışması. & $30 \mathrm{dk}$ \\
\hline & 29. Ders & “h” ve “H” yazıldı. Hece, kelime ve cümle çalışması. & $30 \mathrm{dk}$ \\
\hline & 30. Ders & Dikte çalışması ve hata analizi. Tekrar. Ödevlendirme. & $40 \mathrm{dk}$ \\
\hline \multirow{2}{*}{$\therefore \stackrel{\pi}{\boldsymbol{I}}$} & 31. Ders & “v , V, c ve C” yazıldı. Hece, kelime ve cümle & $30 \mathrm{dk}$ \\
\hline & 32. Ders & “乌̧, Ç, g ve G" yazıldı. Hece, kelime ve cümle & $30 \mathrm{dk}$ \\
\hline
\end{tabular}




\begin{tabular}{|l|l|l|l|}
\hline & 33. Ders & "f , F, p ve P" yazıldı. Hece, kelime ve cümle & $30 \mathrm{dk}$ \\
\cline { 2 - 4 } & 34. Ders & "j" ve “J" yazıldı. Hece, kelime ve cümle yazma. & $30 \mathrm{dk}$ \\
\cline { 2 - 4 } & 35. Ders & Dikte çalışması ve hata analizi. & $40 \mathrm{dk}$ \\
\hline
\end{tabular}

